\title{
The moving and shifting concept of culture
}

$\mathrm{T}$ oday, anthropologists, ethnomusicologists, cultural, and gender scholars are interested in culture not only as it is performed, but as it is continuously done, constructed, maintained through acting, musicking, talking, dancing together. Culture lives, and its elements-or aspects, if you wish-are constantly converging, and articulating into new, moving and shifting formations. In this paper Järviluoma discusses the different ways of understanding the concept of culture, interweaving the ideas with the early twentieth century forms of music making in her own grandmother's home village in northern Finland. She discusses how the new 'culture', within the 'civilising' social movements converged with the old ways of life and musicking.

My GRANdmother MartTa would be celebrating her 110th birthday today (17.8.2011), if she was still among us. She lived her life in a country village in northern Ostrobothnia; she was one of my main interviewees for my Master's Thesis in the mid-1980s.

There are several reasons, why I am referring to my grandmother today, and to this twenty-five-year old thesis. Its name is Musiikki, liikkeet, hillikkeet. Talonpoikaiston ja työväestön musiikinviljely kolmessa Ylivieskan kylässä vuosina 1900-1939 (Järviluoma 1986) - the Finnish-speaking audience will notice that I am using the word musiikinviljely, 'cultivation of music', in the title. However, in English the name goes like this: 'Music, social movements, restraints: The musical culture of peasants and workers in three villages in the Ylivieska region 1900-1939'. The early twentieth century was the time when public educational movements such as the Finnish Youth Association swept all over Finland with the aim of 'civilising' the rural people, including the inhabitants of my grandmother's home town, Ylivieska, as well as her home village (see Frykman \& Löfgren 1984). One of the main aims of my study was to find out whether the existing local forms of music-making changed when the various social movements and associations entered the localities, bringing their own musical policies.

My grandmother and her generation, who were young in the late 1910 s and 1920s, did not apply the word music to their own singing and playing of instruments. She and her neighbours would say to me: 'At that time, it was only rarely that one heard music' (Järviluoma 1986: 27), since they categorised as music only things like organ playing in the church, or harmonium playing as was heard at the village school-on Mothers' Day celebrations for exampleor brass music, radio music, and music heard from gramophone records. At the same time, from my point of hearing as an ethnomusicologist, their own musical 'cultivation' in the 1920 s had been extremely rich, including constant singing, work songs, cow calls, extremely elaborated fiddle playing techniques, and self-organised dance culture.

Professor Jean-Louis Fabiani, just then, asked whether the vocal call performed by Topi Lehtipuu right at the beginning of this panel discussion, when Topi was trying to catch the attention of the audience, could be called culture. I assure you that it definitely is culture, and music. However, it did not occur to the inhabitants of the Finnish countryside a hundred years ago that such sonic signals, for example the very elaborated and expressive ways in which the 'women folk' were calling in the cows in the summer evenings, in order to attract them back home from the forest, could even be called music, not to mention culture.

No wonder that during the 1980 os I found the cultural theories of the German cultural theorist 


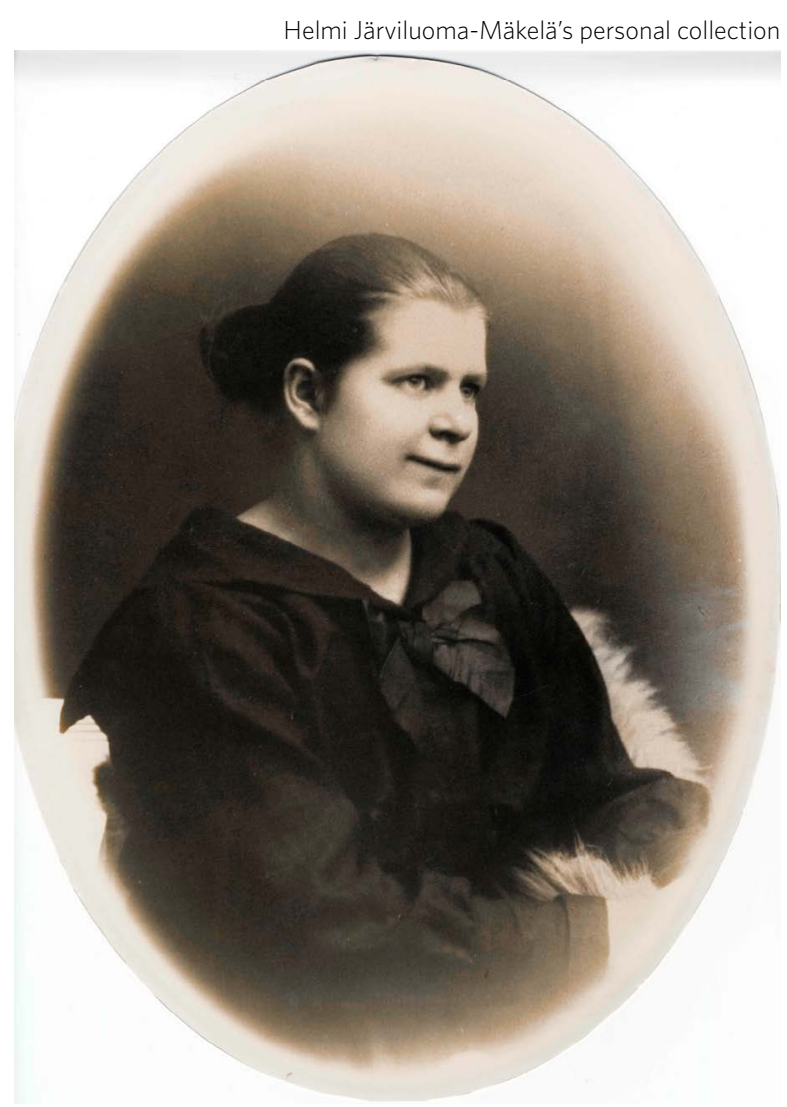

Martta Janiika Isokoski (1901-99) around the year 1918, when her hobby was to act in the theatre of the local Youth Association, 'Rinteen nuorisoseura', in Raudaskylä village in northern Osthrobothia. Later, Martta married Ville Säily, subsequently gave birth to nine children, of which seven reached adulthood, and took care of the family's small cattle herd.

Wolfgang Fritz Haug of the so-called post-Frankfurt school appealing. Haug was popular at that time in Finland. He was developing a materialistic cultural theory that takes everyday culture seriously. He was even referring to a very similar situation to the one I encountered in my home village. When the German workers of the AEG factory in the 1970s were asked, after their workshift had ended, whether they had cultural hobbies, the workers either did not answer at all or said that they didn't have time for culture. They did not realise, continues Haug, that it would have been possible to describe going to the pub after work, playing cards, or telling stories and jokes as cultural activities, and that such activities could even have been considered as an aspect of a conscious workers' culture. (Haug 1983: 124-5)

I really took to the idea of the so-called aspect logics of culture, that is, that culture is not a particular area, but rather that the term 'cultural' can be considered to be an aspect of any social phenomenon. A very common idea according to Haug (1983: 133-5), is to consider culture as an 'area' which can be produced elsewhere according to a certain division of labour and then 'moved' into another class-in the case of AEG, the working class. Haug comes to the following conclusion:
So, herangehend entdecken wir, dass kultur, nicht ein Sachkomplex ist, sondern ein As- peckt in der Gesamtheit der Beziehungen, und zwar der Aspekt, insofern menschen sich ihre Aktivitäten als sinnvoll und sinnlich geniessbar einrichten (Haug 1980: 11).

There is still something very tempting in this definition, although it is of course already more than 30 years old. It has relevant echoes, and a critique (see Haug 1983: 128) of Max Weber's definition of culture. Of course we can also hear in it the age-old discussion of the important Victorian architects of culture from Matthew Arnold to Edward Tylor. Haug can be heard to criticise the idea of culture as the stockpiling of high cultural products; namely, it is often thought that for Arnold being cultured meant acquiring or possessing superior things-poems, music, paintings. However, as Marc Manganaro has recently stated, 'Arnold's argument is not simply about acquiring cultural products; it is complexly concerned with attaining a state of mind that those works can facilitate' (Manganaro 2002: 4). Now, this is not anymore so very far from Haug's idea about culture as an aspect or entity of relationships, and an aspect insofar as people arrange their activities meaningfully and with sensory enjoyment.

In his fascinating account of the emergence of the concept of culture throughout the development of literary studies and anthropology up to 1950, Marc Manganaro $(2002)^{*}$ comes to an interesting conclusion. One of the two 'treatments of culture' he finds most generative, useful, and usable in the last quarter of the twentieth century was written by the anthropologist Zora Neale Hurston (and the other by the literary scholar Kenneth Burke).

This is, in fact, very understandable. Hurston, the African-American folklorist and writer is nowadays considered to have been far ahead of her times: she

* Manganaro concentrates especially on the watershed year of modernism, 1922, when Bronislaw Malinowski's Argonauts of the Western Pacific, T. S. Eliot's The Waste Land, and James Joyce's Ulysses were published. 
is said to have preceded the postmodernist anthropological movement. Zora Neale Hurston strongly anticipated the performative folkloristics of the twentieth century, and built upon the 'conceptions of the orchestrated performance of culture as performative' (Manganaro 2002: 184-5). As Manganaro puts it (p. 185), her work-especially Mules and Men (Hurston 1935) - was not about 'grasping the native's point of view but about inhabiting it'.

There are many aspects in Hurston's work that indeed are nowadays relevant, not only for me, but for many other anthropologists, ethnomusicologists, cultural, and gender scholars. We are interested in culture not only as it is performed, but as it is continuously done, constructed, maintained through acting, musicking, talking, dancing together.

JUST BEFORE THE YEAR 1920 my grandmother Martta played the lead role in a theatrical production in her native village: she was acting the main character, Anna-Liisa in a famous play by Minna Canth. In 1910 the vibrant Finnish Youth Association movement had reached her village, and an Association house had been built, where a new kind of 'culture' was being nurtured. Most certainly, in this movement, culture was, at least to some extent, thought of as an 'area' which could be produced elsewhere (among the leaders or elite of the movement) according to the division of labour and then 'moved' inside the community of rural people. The result in my grandmother's home village was interesting however. The villagers did not give up, straight away, their own ways of music making-instead, the new 'culture' converged with the old ways of life and musicking. This is because culture lives, and its elements-or aspects, if you wish-are constantly converging, and articulating into new, moving and shifting formations.

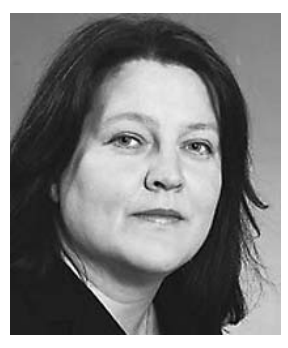

Helmi Järviluoma-Mäkelä is Professor and Head of Cultural Studies at the University of Eastern Finland, and Docent (Adjunct Professor) at the University of Turku. She is currently directing the project Soundscapes and Cultural Sustainability (Academy of Finland). E-mail: helmi.jarviluoma(at)uef.fi.

\section{Literature}

Frykman, Jonas \& Orvar Löfgren 1984. Den kultiverade människan. Lund: Etnologiska sällskapet i Lund.

Haug, Wolfgang Fritz 1980. 'Standpunkt und Perspektive materialistischer Kulturteorie.' In: W. F. Haug \& Kaspar Maase (eds), Materialistischer Kulturteorie und Alltagskultur. Berlin: Das Argument.

-1983. Ideologiset mahdit ja vastarinta. Helsinki: Tutkijaliitto.

Hurston, Zora Neale 1990. Mules and Men. New York: Harper \& Row. (First published in 1935.)

Järviluoma, Helmi 1986. Musiikki, liikkeet, hillikkeet. Talonpoikaiston ja työväestön musiikinviljely kolmessa Ylivieskan kylässä vuosina 1900-1939 (Music, Movement, Restraints). Tampereen yliopiston kansanperinteen laitoksen moniste 11. Tampere: Tampereen yliopisto.

Manganaro, Marc 2002. Culture, 1922: the Emergence of a Concept. Princeton \& Oxford: Princeton University Press. 